\title{
IPTEKS PENGENDALIAN INTERN ASET TETAP FISKAL PADA PT. PLN (PERSERO) UNIT INDUK WILAYAH SULUTTENGGO
}

\author{
Jordy Sinjal $^{1}$, Treesje Runtu ${ }^{2}$ \\ ${ }^{1,2}$ Jurusan Akuntansi, Fakultas Ekonomi dan Bisnis, Universitas Sam Ratulangi, Jl. Kampus Bahu, Kota \\ Manado, 95115, Indonesia \\ Email: jordysinjal@gmail.com
}

\begin{abstract}
PT. PLN (Persero) is stated-owned enterprises of Indonesia that engaged in electricity aspect. PT. PLN (Persero) is demanded by the government to increase social mission and seek profits. The main objective of PT. PLN (Persero) is to distribute electricity to the Indonesian society equally. many buildings, machinery, property and administrative equipment owned by PT. PLN (Persero) must be managed appropriately. Therefore, it takes internal control of fixed assets well to improve employee performance and productivity. A well internal control is needed to keep the fixed assets of a company or entity maintaining the useful life of fixed assets to ease the company operations. Based on the observations of PT. PLN (Persero), internal control of fixed assets already effective and efficient, but there are few things that needs to be concerned such as the completeness of documents and archiving. Archiving is really important for a company because archive is a copy of document made and accepted as a requirement to be fulfilled for administration material, or for material copies or material experience if there is a loss of the original archive.
\end{abstract}

Keywords: Fixed Assets, Internal Control, Completeness of Documents, and Archiving

\section{PENDAHULUAN}

Aset tetap (fixed asset) merupakan aset perusahaan atau entitas yang digunakan untuk kegiatan operasional dan tujuan administratif. Dalam aktivitasnya PT. PLN (Persero) yang termasuk dalam Badan Usaha Milik Negara (BUMN) bertujuan untuk pelayanan umum dan mendukung program pemerintah. Tujuan utama dari PT. PLN (Persero) adalah misi sosial sambil mendapatkan keuntungan sesuai perintah yang diberikan dari pemerintah untuk meningkatkan kesejahteraan masyarakat di Indonesia. PT. PLN (Persero) termasuk dalam bisnis pasar monopoli seperti ciri khas dari BUMN. Oleh karena itu peran PT. PLN (Persero) sangatlah penting. Fungsi dari PT. PLN (Persero) sendiri yaitu untuk mendistribusikan listrik secara merata kepada masyarakat tanpa memandang tingkatan sosial. Hal tersebut dibantu oleh pemerintah dengan subsidi untuk masyarakat. Dalam menjalankan fungsinya sebagai BUMN dalam aspek kelistrikan, PT. PLN (Persero) memiliki satu tujuan utama, yaitu menerangi Indonesia. Dalam lingkungan kerja PT. PLN (Persero) terdapat kelompokkelompok unit, yaitu kelompok unit penunjang, penyaluran dan pusat pengaturan beban, pembangkitan, distribusi, wilayah, transmisi, dan proyek.

PT. PLN (Persero) Unit Induk Wilayah Suluttenggo termasuk dalam kelompok unit wilayah PT. PLN (Persero) yang bertugas mengurus segala aspek kelistrikan yang ada di Wilayah Sulawesi Utara, Sulawesi Tengah, dan Gorontalo. Dalam lingkungan kerjanya PT. PLN (Persero) Unit Induk Wilayah Suluttenggo terdapat 5 bagian, yaitu bagian perencanaan, bagian distribusi, bagian niaga dan pelayanan pelanggan, bagian keuangan, dan bagian sumber daya manusia dan umum. Pengelolaan Aset tetap (fixed asset) pada PT. PLN (Persero) Unit Induk Wilayah Suluttenggo diterapkan secara komprehensif oleh karyawan di setiap bagian. Dikarenakan beragamnya bagian di PT. PLN (Persero) Wilayah Suluttenggo diperlukan pengklasifikasian aset untuk dapat membedakan aset di tiap bagian. Aset Tetap 
adalah barang yang terlihat wujudnya dan memiliki setidaknya bisa digunakan lebih dari satu periode. Contoh dari aset tetap seperti bangunan, properti, kendaraan, mesin, peralatan administrasi, dan lain-lain. Aset tetap memiliki nilai penyusutan tersendiri di setiap periode.

\section{TINJAUAN PUSTAKA}

Badan Usaha Milik Negara (BUMN). Sesuai dengan Peraturan Menteri BUMN PER-13/MBU/09/2014 dapat diambil kesimpulan bahwa dalam suatu negara sangat penting memiliki suatu perusahaan yang dibentuk oleh pemerintahan. Badan Usaha Milik Negara berbeda dengan badan lain yang dibentuk oleh pemerintah. Perbedaannya adalah status badan hukum dan sifat operasionalnya. BUMN lebih bertujuan untuk meningkatkan kesejahteraan masyarakat dengan cara memenuhi kebutuhan sosialnya. BUMN terdapat beberapa macam, seperti perusahaan jawatan, perusahaan umum, perusahaan perseroan, perusahaan daerah, dan koperasi.

Akuntansi. Menurut Soemarso. S. Pengertian akuntansi adalah pengikhtisaran, penggolongan, pengelompokan, dan pengolahan data sehingga menjadi laporan keuangan yang bermanfaat bagi pihak-pihak yang berkepentingan. Proses yang berawal dari terjadinya transaksi sampai neraca saldo setelah penutupan harus dibuat secara efektif dan efisien serta hasilnya dapat dipertanggungjawabkan oleh pembuat.

Pengendalian Intern. Agoes (2012 : 100) pengendalian intern merupakan perencanaan tentang manajemen atas aset, serta kebijakan-kebijakan yang dibentuk agar tercapainya efektifitas dan efisiensi operasional.

Aset Tetap (Fixed Asset). Sesuai Pernyataan Standar Akuntansi Keuangan (PSAK) No. 16 (2015) aset tetap yang dimiliki oleh perusahaan atau entitas tertentu yang memiliki fungsi dalam kegiatan operasional. Aset tetap berfungsi untuk membantu mempermudah kegiatan operasional. Pengendalian intern aset tetap PT. PLN (Persero) Unit Induk Wilayah Suluttenggo menerapkan Edaran Direksi PT. PLN (Persero) Nomor: 0006.E/DIR/2017 Tentang Pedoman Kebijakan Aset Tetap Fiskal PT. PLN (Persero).

\section{METODE DAN TEKNIK PENERAPAN IPTEKS}

\subsection{Metode Penerapan Ipteks}

Metode Penerapan Ipteks yang diterapkan adalah menguraikan pengendalian intern aktiva tetap yang ada di PT. PLN (Persero) Unit Induk Wilayah Suluttenggo dengan cara menganalisis pengendalian intern aktiva tetap yang diterapkan seperti mulainya penyusutan, metode penyusutan, dasar penyusutan, pengelompokan harta, tarif penyusutan, kebijakan fiskal penilaian kembali atas aset tetap, penilaian kembali aset tetap PLN, perubahan metode pembukuan, dan ketentuan penyusutan fiskal lainnya.

\subsection{Teknik Penerapan Ipteks}

Teknik Ipteks yang diterapkan adalah dengan wawancara dengan pihak yang bersangkutan, mengumpulkan dokumen yang terkait, arsip, dan regulasi pedoman mengenai kebijakan aset tetap fiskal PT. PLN (Persero).

\section{PEMBAHASAN}

\subsection{Gambaran Objek Penerapan Ipteks}

PT. PLN (Persero) Unit Induk Wilayah Suluttenggo beralamat di Jl. Bethesda No.32, Ranotana, Sario, Kota Manado, Sulawesi Utara. PT. PLN (Persero) Unit Induk Wilayah Suluttenggo merupakan kelompok unit wilayah PT. PLN (Persero) di Manado. Kebutuhan masyarakat yang berada di daerah Sulut, Sulteng, dan Gorontalo terhadap listrik membuat PT. PLN (Persero) mendirikan kelompok unit wilayah yang berada di Sulawesi Utara. PT. PLN (Persero) kelompok unit wilayah membawahi transmisi, distribusi, dan pembangkitan 
sekaligus. Dalam lingkungan kantor PT. PLN (Persero) Unit Induk Wilayah Suluttenggo terdapat 2 bagian lain, diantaranya UIP dan Distribusi.

\subsection{Pembahasan}

Pengendalian intern aktiva tetap dalam PT. PLN (Persero) Unit Induk berjalan lurus sesuai dengan Edaran Direksi PT. PLN (Persero) Nomor: 0006.E/DIR/2017 Tentang Pedoman Kebijakan Aset Tetap Fiskal PT. PLN (Persero). Ada beberapa ruang lingkup yang mempengaruhi:

Mulainya Penyusutan. Penyusutan berawal dari tahun terjadinya pengeluaran, selain untuk aset yang sedang dalam proses pembuatan, penyusutannya ketika bulan selesainya pembuatan aset tersebut, sepanjang aset tersebut telah memberikan manfaat kepada perusahaan. PLN dibolehkan membuat penyusutan dari awal tahun aset tersebut dipakai untuk memperoleh, menagih, dan memelihara pendapatan atau pada saat pendapatan yang bersangkutan menghasilkan yaitu pada awal berproduksi dan bukan pada waktu penghasilan diterima atau diperoleh setelah mendapat persetujuan dari Direktur Jenderal Pajak.Saat awal dimulainya penyusutan aset tetap fiskal adalah mengikuti pengakuan aset tetap komersial, kecuali ditentukan lain dengan peraturan perundang-undangan di bidang perpajakan.

Metode Penyusutan. Metode penyusutan yang digunakan adalah Metode Saldo Menurun dan Metode Garis Lurus. Penggunaan metode penyusutan yang dimaksud diatas harus dilakukan dengan taat azas atau secara konsisten, tanpa melihat tingkat profitabilitas PLN dan pertimbangan perpajakan.

Dasar Penyusutan. Dasar penyusutan yang dilakukan dalam suatu tahun pajak merupakan nilai perolehan yang sesuai dengan nilai perolehan komersial di tahun pajak untuk kelompok aset tersebut ditambah dengan perbaikan, perubahan atau pepenambahan dan yang akan dikurangkan dengan pengurangan atau jumlah nilai perolehan dari setiap kelompok harta kecuali ditentukan lain oleh ketentuan dan peraturan perundang-undangan di bidang perpajakan. Pengeluaran untuk memperoleh aset tetap tidak dibebankan sekaligus pada tahun pengeluaran, tetapi dialokasikan secara sistematis selama umur manfaatnya.

Pengelompokan Harta. Pengelompokan harta berwujud untuk menghitung besarnya penyusutan yaitu kelompok harta berwujud yang berupa bangunan dan kelompok harta berwujud yang bukan berupa bangunan. Total awal dari kelompok bangunan dalam suatu tahun pajak harus sama dengan dasar penyusutan periode sebelumnya yaitu sebesar nilai perolehan. Jenis-jenis aset yang termasuk dalam kelompok aset tetap sebagaimana dimaksud pada poin pertama diatas, diatur dengan Keputusan Menteri Keuangan Republik Indonesia dan ketentuan tersebut tidak berlaku apabila harta dialihkan untuk tujuan bantuan sumbangan, hibah yang tidak ada hubungan dengan usaha, pekerjaan, kepemilikkan, atau pengusahaan antara pihak-pihak yang bersangkutan. Penentuan/penetapan umur manfaat, metode dan tarif penyusutan untuk setiap jenis aset tetap PLN (berlaku untuk semua fungsi yang ada dalam pengelompokkan aset tetap PLN) sebagaimana pada Lampiran II. Harta berwujud bukan bangunan dikelompokkan sesuai ketentuan di perusahaan dan peraturan perundang-undangan dalam bidang perpajakan. Harta berwujud bukan bangunan yang terdapat di perusahaan tetapi tidak tercantum dalam peraturan perundang-undangan di bidang perpajakan, maka untuk kepentingan penyusutan digunakan umur manfaat dalam kelompok 3 .

Tarif Penyusutan. Tarif yang digunakan sebagai dasar perhitungan penyusutan harta berwujud seperti pada umumnya.

Kebijakan Fiskal Atas Penilaian Kembali Aset Tetap. Penilaian kembali aset tetap yang telah dilakukan dengan ketentuan, yaitu masa penggunaan fiskal untuk aset tetap yang telah dilakukan penilaian kembali, disesuaikan kembali menjadi umur manfaat penuh untuk kelompok aset tetap tersebut, perhitungan penyusutan dimulai sejak bulan dilakukannya penilaian kembali aset tetap PLN dengan cara perhitungan sebagaimana dimaksud pada Lampiran I, dasar penyusutan atas harta dihitung berdasarkan nilai setelah dilakukan 
penilaian kembali aset tetap PLN, penilaian kembali aset tetap PLN dilakukan setelah jangka waktu lima tahun sejak aset yang dinilai kembali PLN terakhir yang dilakukan berdasarkan Peraturan Menteri Keuangan, dan aset tetap yang dinilai kembali PLN dilakukan berdasarkan nilai wajar aset tetap atau nilai pasar tersebut yang berlaku pada saat aset tetap yang dinilai kembali yang ditetapkan oleh perusahaan jasa penilai atau ahli penilai, yang pemerintah izinkan.

Penilaian Kembali Aset Tetap PLN. Penghitungan penyusutan atas harta yang dilakukan penilaian kembali aset tetap dimulai sejak tanggal 1 Januari 2016 sesuai dengan Keputusan Direktur Jenderal Pajak tentang Persetujuan Penilaian Kembali Aset Tetap. Aset tetap yang dinilai kembali dilakukan terhadap harta berwujud yang terletak di Indonesia, dipergunakan, dan dimiliki untuk menagih, mendapatkan, dan memelihara penghasilan oleh PLN. Apabila dilakukan aset tetap yang dinilai kembali PLN setelah aset tetap yang dinilai kembali terakhir maka penghitungan penyusutan atas harta dilakukan sebagaimana dimaksud pada huruf $F$.

Perubahan Metode Pembukuan. Perubahan metode pembukuan dari Metode Saldo Menurun menjadi Metode Garis Lurus, dilakukan dengan ketentuan, yaitu perubahan Metode Pembukuan dari Metode Saldo Menurun menjadi Metode Garis Lurus berlaku mulai tahun pajak 2017. Sebelum tahun pajak 2017, penyusutan atas masing-masing kelompok 1, 2, 3, dan 4 dilakukan pada beberapa bagian yang menurun selama umur manfaat, yang dihitung menggunakan cara menerapkan tarif penyusutan atas nilai sisa buku, pada akhir umur manfaat nilai sisa buku disusutkan sekaligus.Mulai tahun pajak 2017, penyusutan dilakukan dalam bagian-bagian yang sama besar selama umur manfaat, dasar penyusutan adalah nilai sisa buku dibagi sisa umur manfaat.Mulai tahun pajak 2017, penyusutan atas aset tetap baru dilakukan pada beberapa bagian yang sama besar selama masa guna yang ditetapkan bagi harta tersebut dan dasar penyusutan yaitu sebesar harga atau nilai perolehan.

Ketentuan Penyusutan Fiskal Lainnya. Penyusutan fiskal lainnya dilakukan dengan ketentuan, yaitu saat penghentian aset tetap mengikuti penghentian aset tetap komersial, Aset Tetap Tidak Beroperasi (ATTB) tidak dilakukan perhitungan penyusutan fiskal, perlakuan aset tetap fiskal yang mengalami penambahan, perbaikan atau perubahan adalah sesuai dengan ketentuan aset tetap komersial kecuali ditentukan lain oleh ketentuan dan peraturan perundang-undangan di bidang perpajakan, nilai suatu aset tetap setelah berakhirnya umur ekonomis adalah nihil, sehingga semua nilai sisa buku pada akhir umur manfaat harus disusutkan sekaligus sesuai dengan syarat taat asas, sesuai ketentuan dan peraturan perundang-undangan di bidang perpajakan.

\section{KESIMPULAN DAN SARAN}

\subsection{Kesimpulan}

Dapat dilihat bahwa Pengendalian Intern Aset Tetap di PT. PLN (Persero) Unit Induk Wilayah Suluttenggo berjalan secara efisien dan efektif. Dinilai dari pengawasan dan pengendalian yang dilakukan oleh manajemen yang sudah melakukan tugas dan wewenang yang telah ditetapkan. Dengan adanya Peraturan Direksi PT. PLN (Persero) Nomor : 0006.E/DIR/2017 Pengendalian Intern Aset Tetap mempunyai arah lurus untuk kedepannya dan kebijakan tersebut bias menjadi sudut pandang tentang Pengendalian Aset Tetap secara luas.

\subsection{Saran}

Pengendalian Aset Tetap dari PT. PLN (Persero) Unit Induk Wilayah Suluttenggo sudah berjalan efisien dan efektif, tetapi ada beberapa hal yang harus lebih diperhatikan seperti kelengkapan dokumen dan pengarsipan. Dapat dilihat jelas bahwa sistem pengarsipan masih kurang baik karena sistem pengarsipan di PT. PLN (Persero) Unit Induk Wilayah Suluttenggo masih menggunakan cara yang manual yaitu dengan cara fotokopi. Sebaiknya PT. PLN (Persero) Unit Induk Wilayah Suluttenggo menerapkan cara yang mengikuti 
perkembangan jaman, yaitu dengan melakukan scanning terhadap dokumen-dokumen yang akan diarsip.

\section{DAFTAR PUSTAKA}

Fauziyyah, W., Sondakh, J. 2018. Ipteks Efektifitas Pengendalian Intern Aset Tetap Pada Bank Indonesia Kantor Perwakilan Sulawesi Utara. Jurnal Ipteks Akuntansi bagi Masyarakat, 2(2), 16-24.

Kementerian Badan Usaha Milik Negara Republik Indonesia. 2007. Peraturan Menteri Negara Badan Usaha Milik Negara Nomor PER-05/MBU/2007 Tentang Program Kemitraan Badan Usaha Milik Negara Dengan Usaha Kecil Dan Program Bina Lingkungan. Jakarta. Indonesia.

Kementerian Badan Usaha Milik Negara Republik Indonesia. 2014. Peraturan Menteri BUMN PER-13/MBU/09/2014. Jakarta. Indonesia.

Kementerian Badan Usaha Milik Negara Republik Indonesia. Profil Perusahaan PT. PLN (Persero). http://bumn.go.id/pln/halaman/41/tentang-perusahaan.html.

Kementerian Badan Usaha Milik Negara Republik Indonesia. Sejarah Badan Usaha Milik Negara. http://www.bumn.go.id/berita/kategori/0-Sejarah-Singkat.

Keputusan Menteri Keuangan. Keputusan Menteri Keuangan Republik Indonesia No. 476 KMK 01 tahun 1991 Tentang Pengertian Akuntansi. Jakarta. Indonesia.

Makaluas, J., Pontoh, W. 2018. Ipteks Pengendalian Intern Aset Tetap Pada PT. Lumbung Berkat Indonesia. Jurnal Ipteks Akuntansi bagi Masyarakat, 2(1), 1-5.

Nani, S., Pangemanan, S. 2018. Ipteks Pengendalian Intern Terhadap Aset Tetap Dan Persediaan Di Kantor Otoritas Jasa Keuangan/KOJK Provinsi Sulawesi Utara, Gorontalo, Dan Maluku Utara. Jurnal Ipteks Akuntansi bagi Masyarakat, 2(2), 1-5.

Pernyataan Standar Akuntansi Keuangan (PSAK). Pernyataan Standar Akuntansi Keuangan (PSAK) No. 16 (2015) Tentang Aset Tetap. Jakarta. Indonesia.

PT. PLN (Persero). 2017. Edaran Direksi PT. PLN (Persero) Nomor : 0006.E/DIR/2017 Tentang Pedoman Kebijakan Aset Tetap Fiskal PT. PLN (Persero). Jakarta. Indonesia.

PT. PLN (Persero). Profil Perusahaan PT. PLN (Persero). http://www.pln.co.id/tentangkami/profil-perusahaan.

Soemarso, S. 2009. Akuntansi Suatu Pengantar Buku 2 Edisi 3. Jakarta: Salemba Empat. 